\title{
Perbandingan Algoritma C-Means Clustering dan Fuzzy C-Means Clustering
}

\author{
Abi Kabisah Maulillah ${ }^{1}$, Adhi Kusnadi² \\ Program Studi Teknik Informatika, Fakultas Teknik dan Informatika, Universitas Multimedia \\ Nusantara, Tangerang, Indonesia \\ kabisah@gmail.com \\ adhi.kusnadi@umn.ac.id \\ Diterima: 08 November 2018 \\ Disetujui: 24 Juni 2019
}

\begin{abstract}
Salah satu operasi di dalam analisis citra adalah segmentasi citra. Pada mulanya proses segmentasi dilakukan untuk memisahkan objek dari latar belakangnya, sehingga segmentasi merupakan bagian penting dalam pengenalan objek. Saat ini segmentasi sudah mengalami perkembangan yang sangat pesat, bukan hanya untuk tujuan pengenalan objek saja tetapi juga untuk persoalan interpretasi citra, yaitu untuk mengetahui objek-objek yang termuat dalam suatu citra. Banyak algoritma sudah dikembangkan untuk proses segmentasi citra. Beberapa di antaranya adalah algoritma C-Means Clustering dan Fuzzy C-Means Clustering. Pada peneltian ini, dilakukan perbandingan antara algoritma $C$-Means Clustering dan Fuzzy $C$-Means Clustering dalam segmentasi citra. Dari beberapa hasil percobaan yang didapat dalam penelitian ini berupa sisi waktu atau kecepatan, ketelitian dan pengulangan, maka dapat disimpulkan algoritma Fuzzy C-Means Clustering adalah algoritma yang terbaik yang dapat digunakan dalam segmentasi citra karena dalam algoritma Fuzzy C-Means Clustering terdapat nilai keanggotaan atau fuzzy yang secara iteratif diperbaiki hingga mencapai keadaan konvergen.
\end{abstract}

Index Terms-C-Means Clustering, Fuzzy C-Means Clustering, segmentasi citra

\section{PENDAHULUAN}

Citra merupakan gambar pada bidang dua dimensi. Sebuah citra kaya akan informasi, bahkan ada peribahasa yang berbunyi "sebuah gambar bermakna lebih dari seribu kata". Maksudnya tentu sebuah gambar dapat memberikan informasi lebih banyak daripada informasi tersebut disajikan dengan sejumlah kata-kata (tekstual). Namun demikian perlu cara yang tepat untuk menggali atau mengekstrak informasiinformasi tersebut. Salah satunya adalah dengan melakukan proses segmentasi citra.

Proses segmentasi yang dapat digunakan adalah dengan metode pengelompokan (clustering) berdasarkan warna. Banyak algoritma sudah dikembangkan untuk proses segmentasi citra. Beberapa di antaranya adalah algoritma C-Means Clustering dan Fuzzy C-Means Clustering. Menurut
[10] dari kedua algoritma ini, algoritma C-Means Clustering adalah algoritma yang paling cepat. Oleh karena itu, dalam penelitian ini diteliti manakah dari kedua algoritma tersebut yang paling tepat dan konvergen untuk proses segmentasi citra.

Untuk citra masukannya digunakan citra true color (RGB), dimana menurut [9] jumlah kombinasi warna yang mungkin untuk format citra ini adalah $2^{24}$ atau lebih dari 16 juta warna. Dengan demikian bisa dianggap mencakup semua warna yang ada, inilah sebabnya dalam penelitian ini citra true color (RGB) digunakan.

\section{TINJAUAN PUSTAKA}

\section{A. Citra}

Secara harfiah, citra (image) adalah gambar pada bidang dwimatra (dua dimensi). Ditinjau dari sudut pandang sistematis, citra merupakan fungsi continue dari intensitas cahaya pada bidang dwimatra (2D)[9]. Sumber cahaya menerangi objek, objek memantulkan kembali sebagian dari berkas cahaya tersebut. Pantulan cahaya ini ditangkap oleh alat-alat optik, misalnya mata pada manusia, kamera, scanner dan sebagainya, sehingga bayangan objek yang disebut citra tersebut terekam.

\section{B. Segmentasi Citra}

Klasifikasi citra merupakan proses pengelompokan pixel pada suatu citra ke dalam sejumlah class (kelas), sehingga setiap kelas dapat menggambarkan suatu entitas dengan ciri-ciri tertentu[3]. Menurut [6] metode klasifikasi dapat dikelompokkan menjadi dua, yaitu metode klasifikasi terbimbing dan metode klasifikasi tak terbimbing.

Dalam klasifikasi terbimbing, pemilihan kelas dilakukan dengan cara membandingkan karakteristik data dengan karakteristik kelas data yang sudah diketahui sebelumnya. Sedangkan pada klasifikasi tak terbimbing, data dimasukkan ke dalam kelas data yang 
belum diketahui karakteristiknya, bisa disebut cluster. Proses cluster ini disebut clustering. Tujuan dari segmentasi citra pada prinsipnya sama dengan tujuan dari clustering. Dalam penelitian ini digunakan metode klasifikasi tak terbimbing.

Secara formal segmentasi adalah membagi suatu citra menjadi wilayah-wilayah yang homogen berdasarkan kriteria keserupaan tertentu antara derajat keabuan suatu piksel dengan derajat keabuan pikselpiksel tetangganya[13]. Segmentasi citra dapat didefinisikan sebagai proses membagi suatu citra $\mathrm{R}$ ke dalam beberapa daerah $\mathrm{R} 1, \mathrm{R} 2, \ldots, R n$..

Menurut [12] algoritma segmentasi secara umum berbasiskan pada salah satu dari dua sifat dasar nilai intensitas, yaitu:

a. Diskontinu: membagi suatu citra berdasarkan perubahan besar nilai intensitas (seperti sisi). Algoritma ini biasanya didahului dengan proses edge detection.

b. Similaritas: membagi suatu citra berdasarkan similaritas sesuai kriteria tertentu yang sudah didefinisikan, salah satu algoritma yang termasuk dalam kelompok ini adalah algoritma yang berdasarkan proses clustering.

\section{Konsep Jarak}

Penentuan fungsi keputusan menurut metode klasifikasi ini berdasarkan jarak minimum. Jika sudah diketahui informasi sampel kelas A dan kelas B, dan ingin mengklasifikasikan suatu objek $\mathrm{x}$, maka yang dilakukan adalah mencari jarak terdekat antara objek $\mathrm{x}$ tersebut dengan rata-rata tiap kelas. Berdasar pada pendefinisian "jarak", paling tidak ada dua metode yang termasuk ke dalamnya yaitu Euclides Distance dan Mahalanobis Distance[5]. Dalam penelitian ini akan digunakan Euclides Distance atau jarak Euclides.

\section{Algoritma C-Means Clustering}

C-Means Clustering adalah teknik yang cukup sederhana dan cepat dalam pekerjaan pengelompokan secara iteratif centroid ini diperbaiki hingga konvergen. Perubahan ini diukur menggunakan fungsi objektif $\mathbf{J}$ yang umumnya didefinisikan sebagai jumlah atau rata-rata jarak tiap data dengan centroid.

\section{E. Algoritma Fuzzy C-Means Clustering}

Metode ini dikembangkan oleh Dunn pada tahun 1973 dan diperbaiki oleh Bezdek pada tahun 1981[5]. Algoritma Fuzzy C-Means Clustering (FCM) menganggap setiap piksel dapat bergabung ke dalam beberapa cluster dengan fungsi keanggotaan yang berbeda-beda, tetapi total dari fungsi keanggotaan piksel tersebut harus sama dengan 1. Misalnya piksel ke-1 bisa tergabung dengan cluster 1 dengan fungsi keanggotaan 0.7 , dengan cluster 2 ditebak atau dibangkitkan secara random. Tiap-tiap piksel memiliki fungsi keanggotaan untuk tiap-tiap cluster.
Algoritma FCM bekerja dengan cara mengevaluasi fungsi keanggotaan tiap-tiap piksel secara berulang

\section{PERANCANGAN}

\section{A. Metologi Penelitian}

Untuk melakukan penelitian ini, dilakukan langkah-langkah sebagai berikut :

- $\quad$ Studi literatur

Teori dipelajari dari buku-buku referensi maupun dari website di internet. Agar dapat mendalami materi-materi yang berhubungan dengan topik, serta jurnal-jurnal yang mendukung.

- Desain aplikasi

- Pemrograman aplikasi

- Implementasi dan uji coba

\section{B. Flowchart}

Perbandingan algoritma C-Means Clustering dan Fuzzy C-Means Clustering dalam aplikasi yang dikembangkan dapat dilihat pada gambar flowchart berikut. Gambar 1 adalah flowchart untuk algoritma C-Means Clustering dan pada gambar 2 adalah flowchart untuk algoritma Fuzzy C-Means Clustering

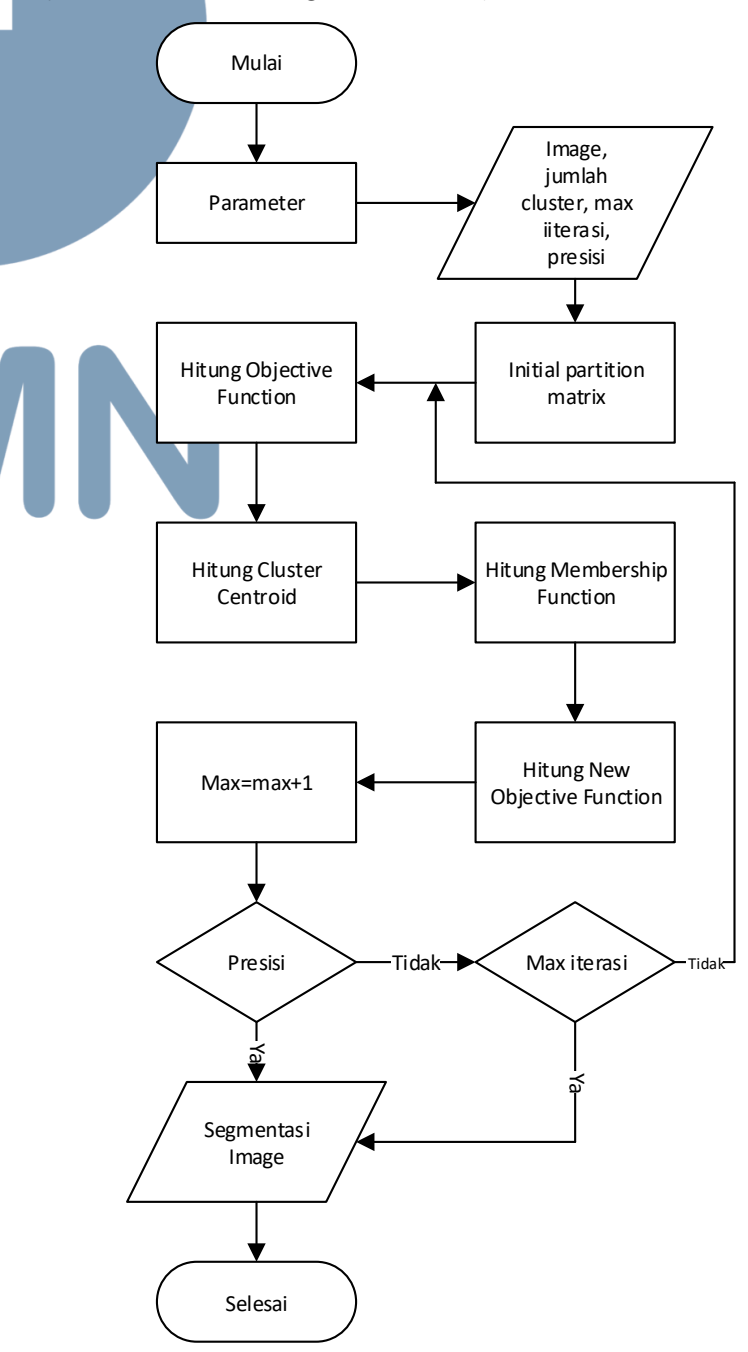


Gambar 1 Flowchart C- Means Clustering

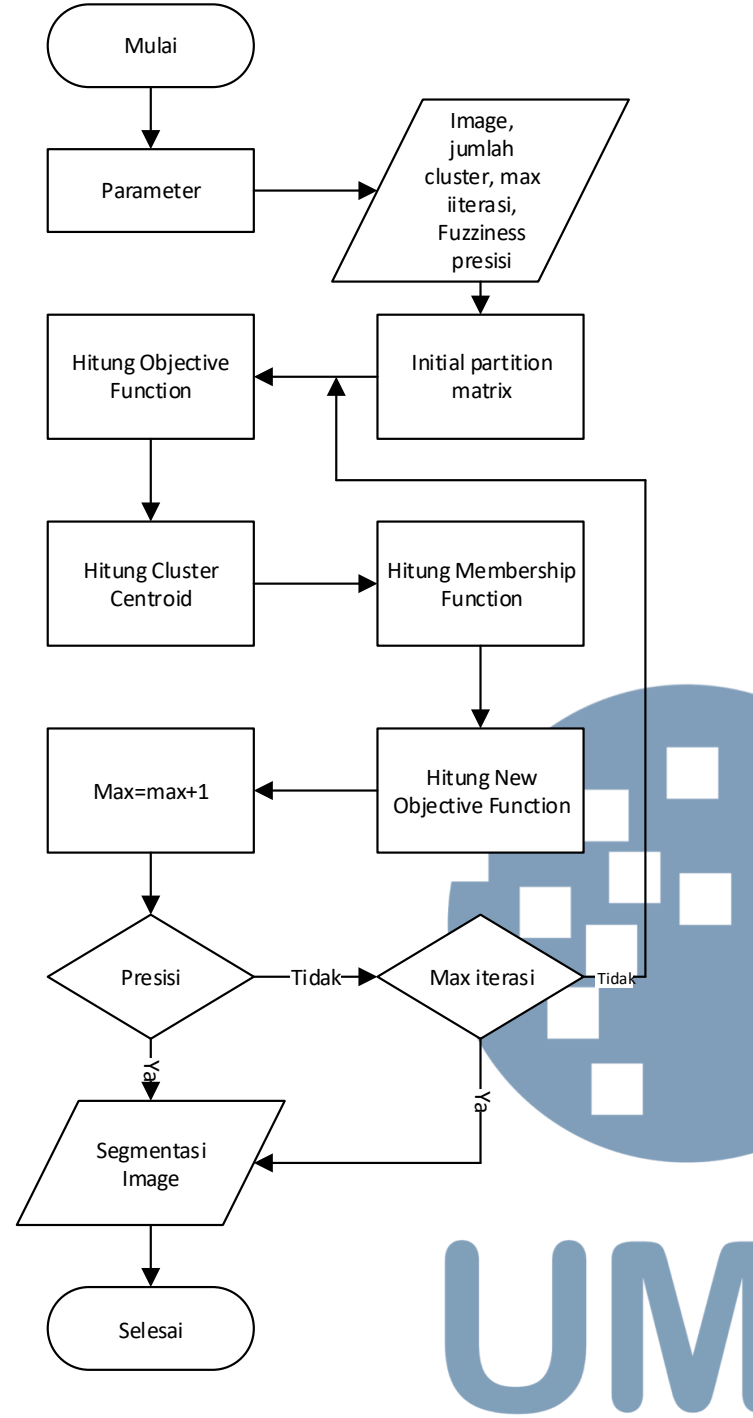

Gambar 2 Flowchart Fuzzy C-Means Clustering

\section{IMPLEMENTASI}

Pengamatan dilakukan terutama pada pengaruh tebakan banyaknya jumlah cluster. Analisa dilakukan terhadap enam buah citra yaitu Lighthouse.jpg yang berukuran 800 x 600 piksel, Desert.png yang berukuran 640 x 480 piksel, dan Sunset.jpg yang berukuran 400 x 300 piksel. Gambar-gambar ini dipilih karena memiliki jumlah warna yang relative banyak. Ukuran gambar dipilih berbeda-beda untuk melihat pengaruh ukuran gambar terhadap kinerja algoritma.

Uji coba dilakukan dengan gambar diuji dengan beberapa setting jumlah dan jumlah iterasi. Tabel 4.1 berikut merupakan hasil dari proses segmentasi yang telah dilakukan:
Tabel 1. Hasil Uji Coba Segmentasi Citra

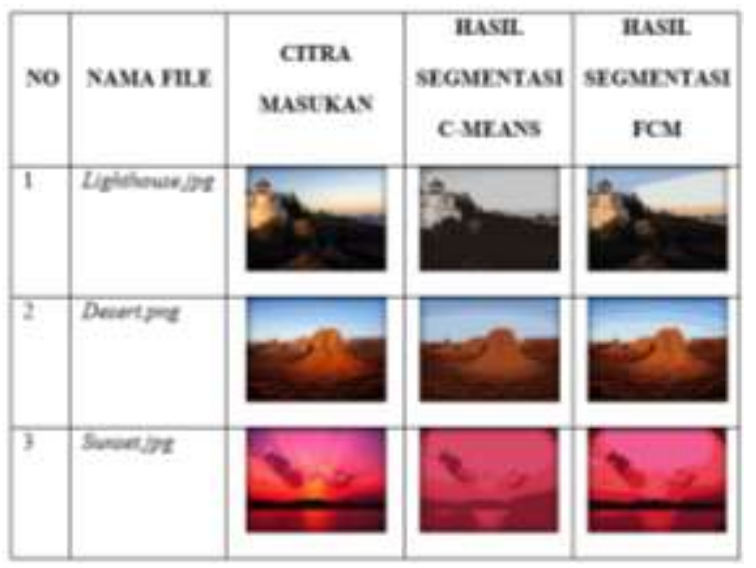

Dari hasil pengujian didapat hasil berupa perbandingan yang disajikan pada tabel 2 .

Tabel 2. Hasil Perbandingan

\begin{tabular}{|c|c|c|c|c|}
\hline No & Algoritma & Citra & Kecepatan & Ketepatan \\
\hline \multirow{3}{*}{1} & \multirow{3}{*}{$\begin{array}{l}\text { Means } \\
\text { Clustering }\end{array}$} & Lighthouse.jpg & $17: 21.48$ & $\begin{array}{c}\text { Iterasi }=20 \\
\text { Presisi }= \\
79069130\end{array}$ \\
\hline & & Desert.png & $18: 02.74$ & $\begin{array}{l}\text { Iterasi }=30 \\
\text { Presisi } \\
=3308240\end{array}$ \\
\hline & & Sunset.jpg & $06: 10.99$ & $\begin{array}{l}\text { Iterasi }=39 \\
\text { Presisi }=0\end{array}$ \\
\hline \multirow{3}{*}{2} & \multirow{3}{*}{$\begin{array}{c}\text { Fuzzy C- } \\
\text { Means } \\
\text { Clustering }\end{array}$} & Lighthouse.jpg & $12: 07.51$ & $\begin{array}{l}\text { Iterasi }=14 \\
\text { Presisi }=0\end{array}$ \\
\hline & & Desert.png & $17: 05.87$ & $\begin{array}{c}\text { Iterasi }=26 \\
\text { Presisi }=0\end{array}$ \\
\hline & & Sunset.jpg & 01:33.71 & $\begin{array}{c}\text { Iterasi }=12 \\
\text { Presisi }=0\end{array}$ \\
\hline
\end{tabular}

Dari tabel 2 dapat dilihat waktu yang dibutuhkan oleh kedua algoritma untuk membuat segemnetasi gambar desert.jpg adalah yang paling besar. Jika di analisa gambar tersebut memiliki area cluster dan warna yang lebih bervariasi dibandingkan dengan kedua gambar lain. Sehingga faktor terbesar bukanlah ukuran file, akan tetapi jumlah area cluster dan variasi warna.

Dan dari tabel 2 juga dapat dilihat rata-rata nilai presisi dalam algoritma Fuzzy C-Means Clustering adalah 0 . Hal ini menyatakan bahwa keadaan seperti ini menandakan proses clustering telah konvergen. Dimana tidak akan mengalami perubahan lagi.

Disimpulkan bahwa algoritma Fuzzy C-Means Clustering adalah algoritma yang paling tepat digunakan dalam segmentasi citra, dimana dari sisi kecepatan dan ketepatannya lebih baik. Tebakan jumlah cluster yang tepat akan memberikan hasil citra tersegmentasi yang informatif. Karena salah satu 


\section{ISSN 2355-3286}

parameter akurasi hasil segmentasi adalah tebakan jumlah cluster dalam bentuk akurasi.

\section{DAFTAR PUSTAKA}

[1] Abraham, A., Grosan, C., \& Ramos, V. 2006. Swarm Intelligence in Data Mining. Berlin: Springer.

[2] Ardisasmita, M. S. 2014, Juni 15. Metoda Segmentasi Citra Resonansi Magnetik Otak Menggunakan Sistem Pengkodean Neurofuzzy. Diambil kembali dari PPINBATAN:

http://www.batan.go.id/ppin/lokakarya/LKSTN10/Syamsa. pdf

[3] Arifin, A. Z., \& Septiana Kurniati, W. D. 2014, Juni 15. Penggunaan Analisa Faktor untuk Klasifikasi Citra PenginderaanJauh Multispektral. Diambil kembali dari Institut TeknologiSepuluhNopember:

http://personal.its.ac.id/files/material/1257- aguszaMakalahJUTI.pdf

[4] Gonzalez, R. C., \& Woods, R. E. 2002. Digital Image Processing. USA: Prentice Hall.

[5] Maimon, O. \& Rokach, L 2005. Data Mining and Knowledge Discovery Handbook. New York: Springer Science+Business Media.

[6] Manalu, J. 2014, Juni 15. Klasifikasi Citra Penginderaan Jauh Menggunakan Teknik Logika Samar (Fuzzy Logic). Diambil kembali dari Warta LAPAN: http://jurnal.lapan.go.id/index.php/warta_lapan/ article/download/924/823

[7] Munir, R. 2014, Juni 15. Aplikasi Image Thresholding untuk Segmentasi Objek. Diambil kembali dari Homepage Rinaldi Munir Sekolah Teknik Elektro dan Informatika ITB: http://informatika.stei.itb.ac.id/ rinaldi.munir/P enelitian/Makalah-1-SNATI-2006.pdf

[8] Ngoen, T. S. 2009. Algoritma dan Struktur Data Bahasa C. Jakarta: Mitra Wacana Media.

[9] Pramitarini, Y. 2014, Juni 15. Analisa Pengiriman Citra Terkompresi JPEG dengan Teknik Spread Spektrum Direct Sequence. Diambil kembali dari EEPIS Repository: http://repo.eepis-its.edu/504/1/1291.pdf

[10] Rhiyan, H. 2014, Juni 12. Perbandingan Metode K-Means dan Fuzzy C-Means Untuk Segmentasi Citra. Diambil kembali dari sinta universitas kristen duta http://sinta.ukdw.ac.id/sinta/resources/sintasrv/ getintro/22043693/eae0b4e6e6c6632b37f8dee0 45093ae4/intro.pdf

[11] Suhendra, A. 2014, Juni 15. Catatan Kuliah Pengantar Pengolahan Citra. Diambil kembali dari

$$
\text { Gunadarma University: }
$$

http://openstorage.gunadarma.ac.id/handouts/S 1_TEKNIKINFORMATIKA/PengolahanCitra. pdf

[12] Taniar, D. 2008. Data Mining and Knowledge Discovery Technologies. New York: IGI Publishing.

[13] Winarno, E. 2009. Pengolahan Citra. Semarang: unisbank. 